\title{
Field Validation of the Effect of Soil Fumigation of Ethanedinitrile (EDN) on the Mortality of Meloidogyne hapla and Carrot Yield Parameters
}

\author{
Ondřej Douda ${ }^{1, *}$, Marie Manasova ${ }^{2}$ (D), Miloslav Zouhar ${ }^{2}$, Jonas Hnatek ${ }^{2,3}$ and Vaclav Stejskal $^{1,2}$ (D) \\ 1 Division of Plant Health, Crop Research Institute Prague, Drnovská 507, \\ 16106 Prague 6, Ruzyně, Czech Republic; stejskal@vurv.cz \\ 2 Department of Plant Protection, Faculty of Agrobiology Food and Natural Resources, \\ Czech University of Life Sciences Prague, Kamýcká 129, 16500 Prague 6, Suchdol, Czech Republic; \\ manasova@af.czu.cz (M.M.); zouhar@af.czu.cz (M.Z.); jonas.hnatek@draslovka.cz (J.H.) \\ 3 Lučební Závody Draslovka a.s., Havlíčkova 605, 28099 Kolín IV, Czech Republic \\ * Correspondence: douda@vurv.cz
}

Citation: Douda, O.; Manasova, M.; Zouhar, M.; Hnatek, J.; Stejskal, V. Field Validation of the Effect of Soil Fumigation of Ethanedinitrile (EDN) on the Mortality of Meloidogyne hapla and Carrot Yield Parameters.

Agronomy 2021, 11, 208.

https://doi.org/10.3390/agronomy 11020208

Received: 4 December 2020

Accepted: 20 January 2021

Published: 22 January 2021

Publisher's Note: MDPI stays neutral with regard to jurisdictional claims in published maps and institutional affiliations.

Copyright: (c) 2021 by the authors. Licensee MDPI, Basel, Switzerland. This article is an open access article distributed under the terms and conditions of the Creative Commons Attribution (CC BY) license (https:/ / creativecommons.org/licenses/by/ $4.0 /)$.

\begin{abstract}
With the increasing importance of soilborne plant pest nematodes and the relatively recent phase-out of methyl bromide as a key soil fumigant, there is an urgent need for new fumigants with good nematicidal properties. Ethanedinitrile (EDN) is a promising fumigant and preparation because of its physical, agrochemical, and nematicidal properties. However, its efficacy against nematode pests of different crops under field conditions has not been fully validated and understood. Therefore, the aim of our study was to evaluate the effect of two concentrations of EDN on the survival of northern root-knot nematodes (Meloidogyne hapla) and on carrot yield and quality under field conditions. The evaluation was performed using naturally infested carrot plots, and EDN application to the soil was followed by covering the treated area with film. A high biological effect was observed for both EDN concentrations tested, with even the lower dose $\left(30 \mathrm{~g} \cdot \mathrm{m}^{-2}\right)$ being sufficient for $M$. hapla suppression. Positive effects of EDN application-likely due to EDN partial conversion into biologically available nitrogen in soil-on carrot root weight, in comparison with the untreated control, were also observed.
\end{abstract}

Keywords: Meloidogyne; soil fumigation; ethanedinitrile

\section{Introduction}

Twelve percent of all crop losses caused by pests can be attributed to nematodes, accounting for annual monetary losses equal to 157 billion USD (United States dollar) [1]. This is especially true for root-knot nematodes belonging to the genus Meloidogyne, which has been reported as the most important genus of plant-parasitic nematodes worldwide [2,3]. For farmers, any type of chemical management of soil-borne plant parasitic nematodes presents challenges. The occurrence of nematodes in lower levels of the soil profile forces growers to apply conventional nematicides at the highest recommended concentrations and doses. Another problem is the general decrease in the number of traditional nematicides available and the lack of development of new and effective substances for crop protection against plant parasitic nematodes. For example, as of 2020, only two conventional nematicides (dazomet and oxamyl) were available for open field application in the Czech Republic. Other aspects hindering the routine application of nematicides are the high prices of these substances and the risks that their application presents for the environment, especially for groundwater reservoirs.

In the agro-climatic and soil conditions of the Czech Republic (CZ), Meloidogyne hapla presents a serious threat to field-grown root vegetables localized on sandy soils of the Elbe lowland [4]. Since the first report of M. hapla in the CZ in 2003 [5], the species has become well established and is causing substantial losses regularly. The frequent and 
abundant occurrence of $M$. hapla in a number of irrigated fields, i.e., those most suited for root vegetable production, leads to an urgent need for efficient management techniques for this pest. Methyl bromide was applied as a soil fumigant for eradication of Meloidogyne sp. until its ban for most purposes at the worldwide scale [6]. Unfortunately, no fully fledged alternative to methyl bromide is currently available. A number of methyl bromide alternatives is currently being investigated, such as dichloropropen, chloropicrin, metolachlor, trifloxysulfuron, metam potassium, iodomethane, dimethyl disulfide, 1,3-dichloropropene, fluensulfone, fluopyram or fosthiazate [7-14]. The effect of hydrogen cyanide as a tool for the fumigation of agricultural and wooden commodities has also been evaluated [15,16]. Ethanedinitrile (EDN) is also a promising methyl bromide alternative since it is a broadspectrum fumigant with herbicidal, insecticidal, fungicidal, and nematicidal activities. Several authors have demonstrated the high activity of EDN against several species of nematodes, such as Bursaphelenchus xylophilus [17-20] and Steinernema carpocapsae [21,22]. Due to its broad-spectrum pesticide activity, EDN has the potential to become an effective preplant soil fumigant. When compared with the abovementioned substances, EDN provided some additional advantages, even from application and agro-technical points of view. For example, it was found that EDN can act even as a fertilizer since after its application, it added a significant amount of nitrogen to the soil [23]. EDN penetrates substrates fairly well and is heavier than air and other gases [24]. Therefore, it is easy to apply and seal under a film using appropriate mechanization, and it decomposes rapidly into nontoxic products [25]. Apart from application techniques, the efficacy of fumigants is also affected by environmental conditions. The important conditions include soil properties, humidity, and temperature [26]. In particular, the temperature affects fumigation due to its influence on invertebrate pest metabolism and breathing rate [27]. All of the degradation products of EDN naturally occur in the soil environment [21].

The main aim of this work was to evaluate the effect of EDN soil application on the viability of Meloidogyne hapla nematodes. An additional goal was to evaluate the effect of an EDN preplant soil treatment on the basic qualitative and quantitative parameters of carrot yield.

\section{Materials and Methods}

Experiments were conducted in a field naturally infested with M. hapla in Litol (Lysá nad Labem, Central Bohemia region, $\left.50^{\circ} 11^{\prime} 3.288^{\prime \prime} \mathrm{N}, 14^{\circ} 50^{\prime} 16.429^{\prime \prime} \mathrm{E}\right)$. The occurrence of $M$. hapla and crop damage in the locality has been observed regularly since at least 2012 [28].

One year before the initiation of the experiments, carrot samples were collected in zigzag patterns from the experimental plot, and the presence of $M$. hapla nematodes was evaluated by estimation of root galling. The homogeneity of the plot infestation was assessed, and the area best suited for the experimental seedbeds was chosen. The northern part of the plot was selected for the parallel establishment of experimental and control variants. The area was divided into eight belts, each $150 \mathrm{~m}$ long and $1.5 \mathrm{~m}$ wide and divided by $1 \mathrm{~m}$ wide gaps. Each area was traced out and prepared for the experiment. Two experimental and two control variants were established. The first experimental variant was treated with EDN at a concentration of $30 \mathrm{~g} / \mathrm{m}^{2}$, and the second variant was treated with EDN at $50 \mathrm{~g} / \mathrm{m}^{2}$. The first control variant was covered with film without EDN application to exclude the potential effect of soil solarization on nematode viability. The second variant was left completely untreated as a control. Each variant was repeated twice. EDN treatment was performed using the modified towed bed mulch layer method with a Rain-Flo 2600 (Dubois Agrinovation, Simcoe, QC, Canada). A pressurized vessel containing EDN was placed on the mulch layer, and EDN was applied to the soil at a depth of $20 \mathrm{~cm}$. The towing speed and EDN flow were adjusted to reach desired concentrations of $30 \mathrm{~g} / \mathrm{m}^{2}$ and $50 \mathrm{~g} / \mathrm{m}^{2}$. The applicator was adjusted to a width of $1 \mathrm{~m}$, constant speed was maintained during the application, and this was verified using GPS (Global Positioning System). The flow rate of EDN (kg per minute) necessary to reach the desired concentration was established and set using the regulation valve. EDN flow was observed during application with the help of a 
flow rate meter placed on the pressurized vessel. The volume of the vessel was $73 \mathrm{~L}$ and it was filled with $50 \mathrm{~kg}$ of EDN. The vessel was not the component of the applicator and was supplied separately (Faber Industrie SpA, Cividale del Friuli, Italy). Immediately after EDN application, the treated area was covered by totally impermeable film (TIF ${ }^{\circledR}$, Raven Industries, Inc., Sioux Falls, SD, USA), which is normally used as a mulch layer (Figure 1, Scheme 1). EDN detectors (MSA, Hopton Park, UK) were placed around the treated area during the application. The covering was removed 14 days after application, and carrots (cultivar Natuna F1, BEJO BOHEMIA, S.R.O., Podůlšany, Czech Republic) were sown on 24 April 2019 into each experimental belt, with four rows of carrots in each plot.

This experimental setup was replicated twice during the course of 2019. The second replication was performed on the experimental plot adjoining the area used for the first experiment. Sowing of carrots was conducted on 1 August in this case.

Afterwards, both the treated and nontreated carrot plants were grown for 90 days under standard field conditions with irrigation. For analysis, 120 carrot plants were randomly picked from each experimental variant, and the following parameters of each plant were assessed: fresh root weight, fresh leaf weight, largest root diameter, root length, and number of root galls. The statistical significance of the variability in the observed parameters was tested by one-way ANOVA followed by post hoc comparisons using the Tukey HSD method. Before ANOVA was applied, data were tested for homogeneity of variance using the Bartlett test (Statistica 13.3, TIBCO Software Inc., Palo Alto, CA, USA). The chemical analysis of nutritional parameters and basic element contents was performed by a commercial laboratory (Laboratoř Postoloprty, s.r.o., Postoloprty, Czech Republic) using standard laboratory protocols. Randomly chosen samples from both EDNtreated replications and untreated control variants (i.e., those not covered by the film) were subjected to these analyses; only the samples from the second experiment established in summer were analyzed in this way.

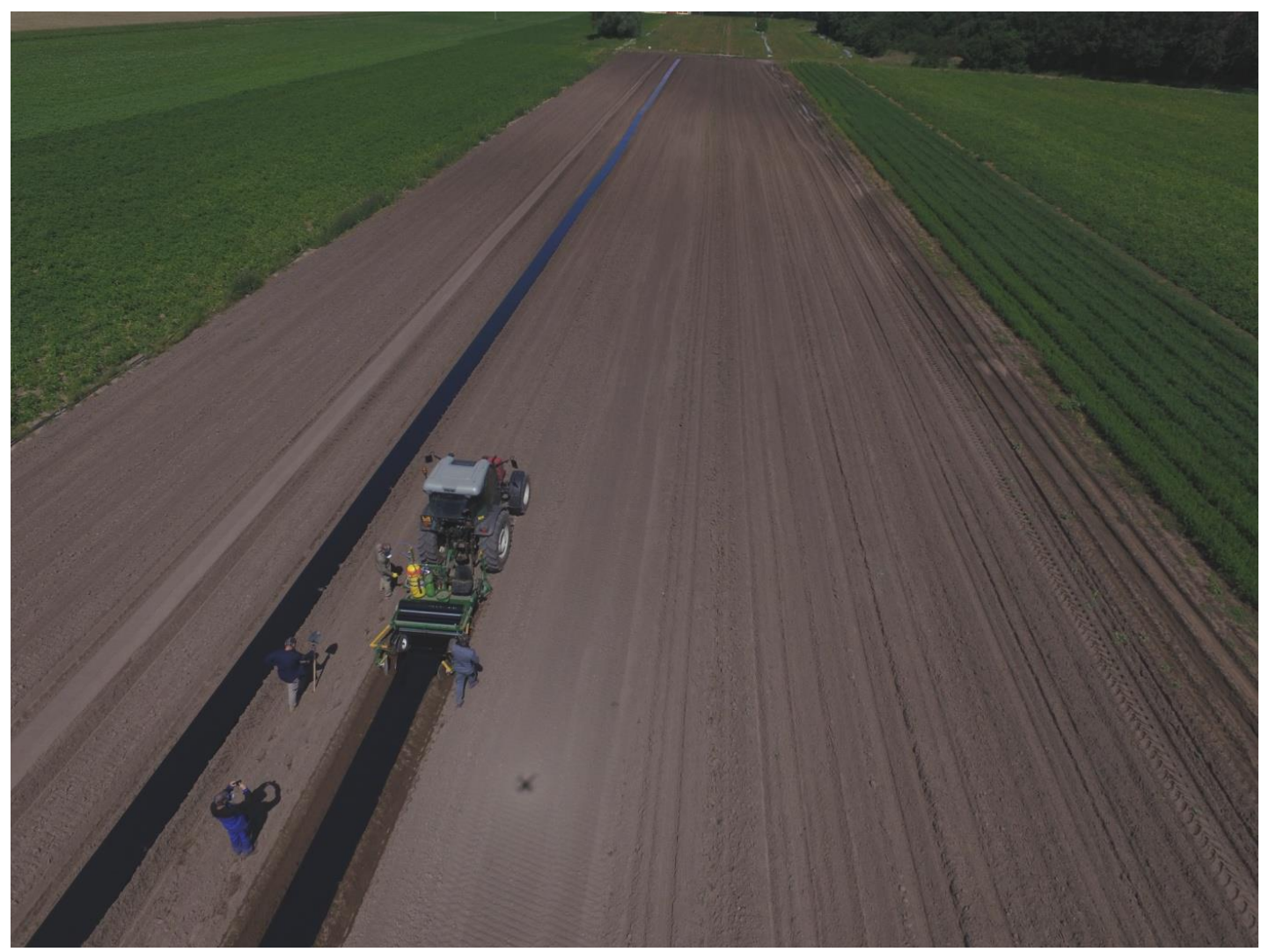

Figure 1. Visualization of the preplant soil treatment with ethanedinitrile (EDN) in the experimental plot using the modified bed mulch layer method (black stripes on soil = plastic cover made from TIF $^{\circledR}$ film). 


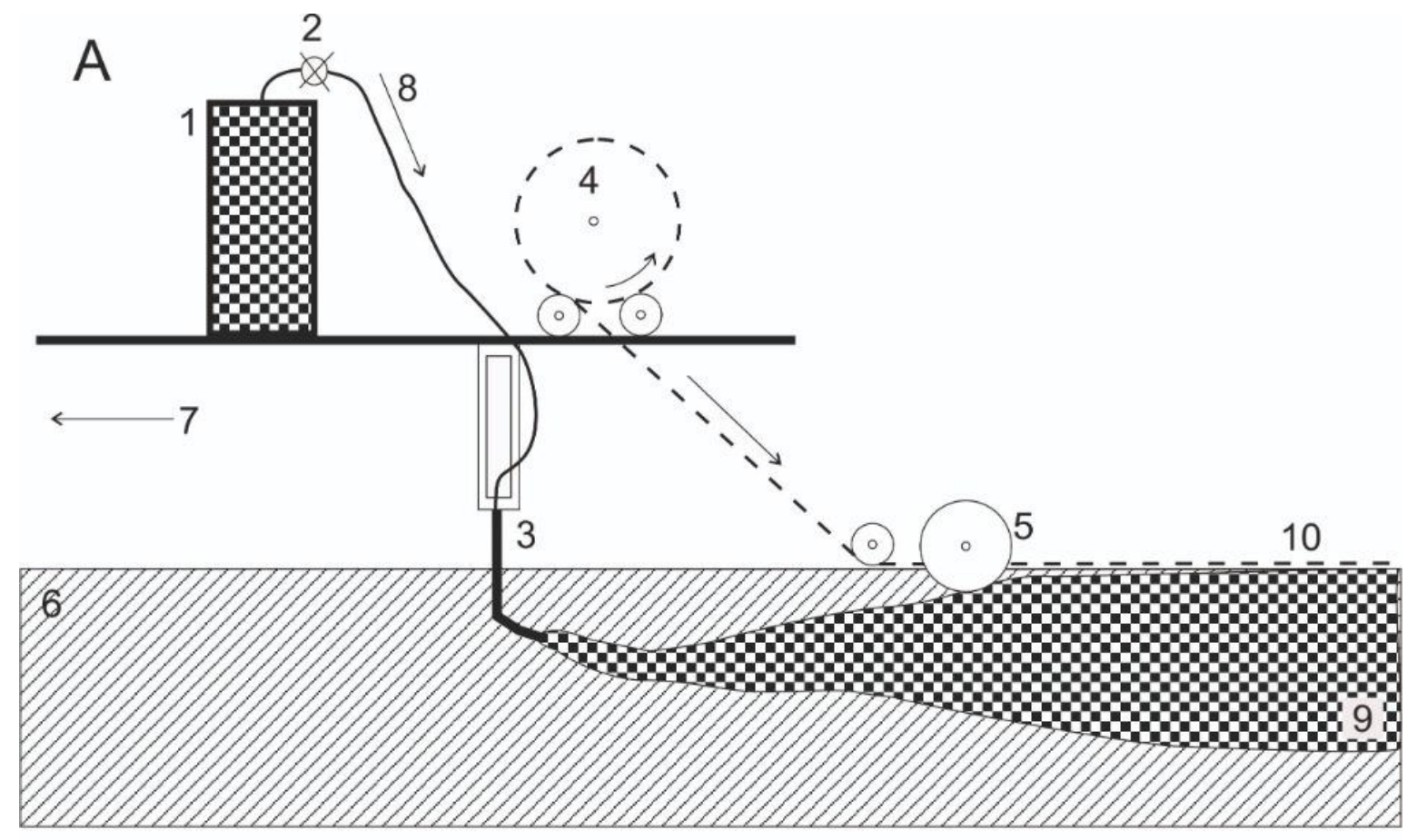

B

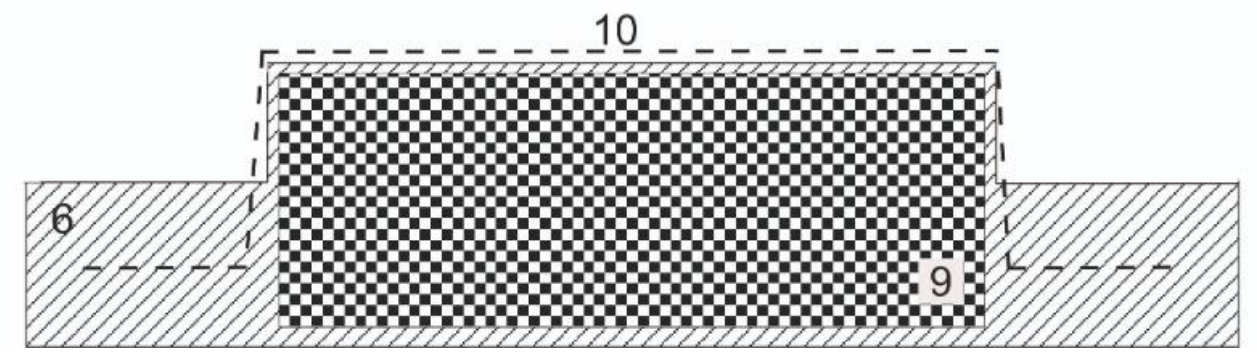

Scheme 1. (A) - Side view of the application device in operation. (B)—Front view of the treated soil profile. 1. pressurized vessel containing EDN. 2. control valve. 3. cultivation blade for EDN application. 4. TIF ${ }^{\circledR}$ film role. 5. cover disk. 6. soil profile. 7. the direction of movement of the application device. 8. the direction of movement of the EDN in the polyethene tube. 9. EDN expanding into the soil profile. 10 . $\operatorname{TIF}^{\circledR}$ film covering the treated area.

\section{Results and Discussion}

All results are summarized in Tables 1 and 2. The effect of EDN application on $M$. hapla presence/absence was clearly apparent from the numbers of root galls observed in treated and untreated variants. Statistically lower numbers of root galls were detected in all EDN-treated variants. Both tested EDN concentrations produced statistically similar results; the lower EDN concentration of $30 \mathrm{~g} / \mathrm{m}^{2}$ was completely sufficient for nematode suppression. On the other hand, both control variants were extensively infested by the nematode (Figure 2). 


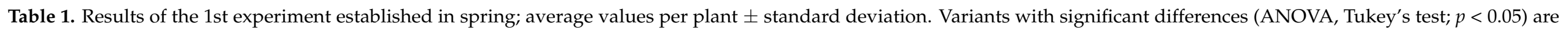
indicated by different letters.

\begin{tabular}{|c|c|c|c|c|c|c|c|}
\hline & Untreated Control 1 & Untreated Control 2 & $\begin{array}{l}\text { Untreated Control } \\
\text { Covered by Sheet } 1\end{array}$ & $\begin{array}{l}\text { Untreated Control } \\
\text { Covered by Sheet } 1\end{array}$ & $30 \mathrm{~g}$ EDN 1 & $30 \mathrm{~g}$ EDN 2 & $50 \mathrm{~g}$ EDN 1 \\
\hline fresh root weight $[\mathrm{g}]$ & $8.3 \pm 6.29^{a}$ & $12.88 \pm 12.21^{b}$ & $12.68 \pm 8.43^{b}$ & $11.20 \pm 8.38^{a, b}$ & $19.18 \pm 13.23^{\mathrm{c}, \mathrm{d}}$ & $17.35 \pm 8.46^{\mathrm{c}}$ & $21.12 \pm 8.97^{\mathrm{d}}$ \\
\hline root length $[\mathrm{cm}]$ & $6.76 \pm 3.59^{a}$ & $7.91 \pm 3.48^{a}$ & $7.25 \pm 3.86^{\mathrm{a}}$ & $7.49 \pm 3.86^{\mathrm{a}}$ & $14.12 \pm 3.21^{b}$ & $15.57 \pm 13.39^{b}$ & $15.67 \pm 9.33^{b}$ \\
\hline largest root diameter [mm] & $12.77 \pm 3.93^{a}$ & $15.28 \pm 10.64^{a, b}$ & $16.69 \pm 17.08^{b}$ & $13.79 \pm 6.51^{\mathrm{a}, \mathrm{b}}$ & $15.86 \pm 3.18^{\mathrm{a}, \mathrm{b}}$ & $16.67 \pm 9.33^{b}$ & $17.18 \pm 3.39^{b}$ \\
\hline fresh leaf weight $[\mathrm{g}]$ & $4.13 \pm 2.32^{\mathrm{a}}$ & $6.31 \pm 3.53^{\mathrm{a}}$ & $6.44 \pm 3.28^{b}$ & $5.39 \pm 3.58^{a, b}$ & $8.43 \pm 3.97^{b, c}$ & $9.82 \pm 11.21^{c}$ & $11.59 \pm 6.30^{c}$ \\
\hline gall number & $32.53 \pm 25.78^{a}$ & $51.52 \pm 38.02^{b}$ & $52.07 \pm 38.08^{b}$ & $55.60 \pm 40.43^{b}$ & $3.64 \pm 10.66^{c}$ & $0.87 \pm 2.08^{c}$ & $1.33 \pm 3.37^{c}$ \\
\hline
\end{tabular}

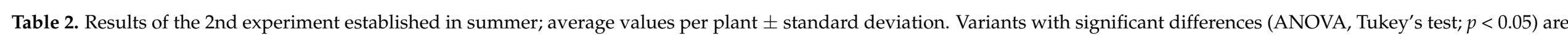
indicated by different letters.

\begin{tabular}{|c|c|c|c|c|c|c|c|}
\hline & Untreated Control 1 & Untreated Control 2 & $\begin{array}{l}\text { Untreated Control } \\
\text { Covered by Film } 1\end{array}$ & $\begin{array}{l}\text { Untreated Control } \\
\text { Covered by Film } 1\end{array}$ & 30 g EDN 1 & 30 g EDN 2 & $50 \mathrm{~g}$ EDN 1 \\
\hline fresh root weight $[\mathrm{g}]$ & $21.68 \pm 15.73^{\mathrm{a}}$ & $17.45 \pm 14.21^{\mathrm{a}}$ & $25.62 \pm 17.94^{\mathrm{a}}$ & $21.93 \pm 17.46^{\mathrm{a}}$ & $46.50 \pm 22.24^{b}$ & $37.34 \pm 17.98^{c}$ & $50.78 \pm 32.28^{b}$ \\
\hline root length $[\mathrm{cm}]$ & $11.66 \pm 13.75^{\mathrm{a}, \mathrm{b}}$ & $8.94 \pm 4.26^{\mathrm{a}}$ & $10.85 \pm 3.68^{a, b}$ & $10.38 \pm 3.44^{\mathrm{a}, \mathrm{b}}$ & $15.39 \pm 2.82^{\mathrm{a}}$ & $16.01 \pm 12.56^{a}$ & $15.97 \pm 2.48^{a}$ \\
\hline largest root diameter [mm] & $18.44 \pm 6.25^{\mathrm{a}}$ & $16.76 \pm 5.24^{\mathrm{a}}$ & $19.24 \pm 5.47^{\mathrm{a}}$ & $20.21 \pm 18.44^{\mathrm{a}}$ & $26.28 \pm 28.78^{b}$ & $21.37 \pm 4.27^{\mathrm{a}}$ & $24.25 \pm 4.40^{\mathrm{a}, \mathrm{b}}$ \\
\hline fresh leaf weight $[\mathrm{g}]$ & $5.49 \pm 3.24^{a}$ & $5.30 \pm 5.77^{a}$ & $5.77 \pm 3.51^{a}$ & $5.22 \pm 3.10^{a}$ & $9.69 \pm 4.03^{b, c}$ & $8.75 \pm 3.83^{b}$ & $10.59 \pm 6.69^{b, c}$ \\
\hline gall number & $35.91 \pm 34.00^{\mathrm{a}}$ & $29.84 \pm 33.75^{\mathrm{a}}$ & $24.11 \pm 30.24^{\mathrm{a}, \mathrm{b}}$ & $21.03 \pm 26.60^{b}$ & $0.24 \pm 0.99^{c}$ & $0.42 \pm 1.30^{c}$ & $0.37 \pm 1.11^{c}$ \\
\hline
\end{tabular}




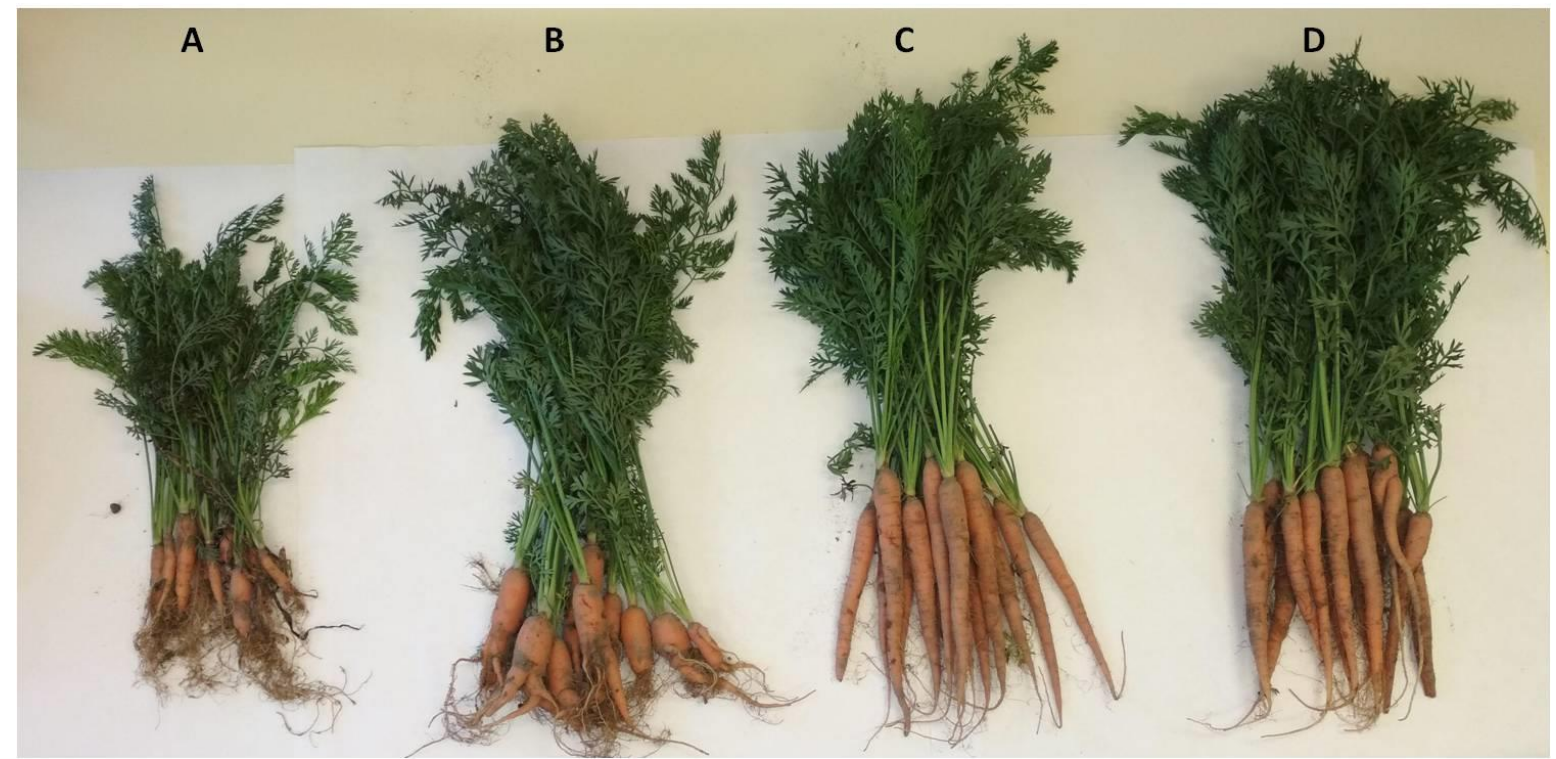

Figure 2. Samples of carrots from the experimental field; (A)—untreated control, (B)—untreated control covered by TIF ${ }^{\circledR}$ film, (C) $-30 \mathrm{~g} / \mathrm{m}^{2}$ of EDN applied, (D) $-50 \mathrm{~g} / \mathrm{m}^{2}$ of EDN applied.

Although the duration of the soil being covered by the film was relatively short, a certain effect of soil solarization could be observed in the experiment established in summer, but this was not the case in the first experiment; spring temperatures were apparently insufficient to suppress nematode viability.

Significantly higher fresh root weight was observed in the variants treated with EDN. Higher weights of carrot plant samples were detected in EDN-treated plots of both experimental terms. Weights tended to be higher in the variants treated with an EDN concentration of $50 \mathrm{~g} / \mathrm{m}^{2}$. However, the differences in carrot weight between variants treated with 30 and $50 \mathrm{~g} / \mathrm{m}^{2}$ were not statistically significant. Considering fresh leaf weight, the effect of EDN treatment was more apparent in the second term of the experiment, and higher leaf weights were detected in the experiment established in spring; however, the difference was not statistically significant in one case. No significant differences in this parameter were observed between both tested EDN concentrations, although leaves of variants treated with $50 \mathrm{~g}$ of EDN were slightly heavier. Root length was significantly higher in EDN-treated variants in the first term of the experiment established in spring only, and a difference was observed in the second term of the experiment only between EDN-treated variants and untreated controls covered by film. No differences between the EDN concentrations were detected. Root diameter was not affected by EDN application, and a significant difference from the untreated control was detected in only one EDNtreated variant. The results of nutritional and basic element analyses are presented in Tables 3 and 4, respectively. A higher content of nitrate anions in variants treated with EDN was clearly apparent. 
Table 3. Nutritional parameters and basic element contents of fresh carrot roots.

\begin{tabular}{|c|c|c|c|c|}
\hline Parameter & Unit & Untreated Control & $30 \mathrm{~g} / \mathrm{m}^{2}$ & $50 \mathrm{~g} / \mathrm{m}^{2}$ \\
\hline Dry mass & $\%$ & 12.9 & 11 & 10.6 \\
\hline N-total & $\%$ & 1.3 & 1.6 & 1.53 \\
\hline $\mathrm{P}$ & $\%$ & 0.3 & 0.28 & 0.35 \\
\hline K & $\%$ & 2.62 & 2.79 & 2.81 \\
\hline $\mathrm{Ca}$ & $\%$ & 0.29 & 0.22 & 0.27 \\
\hline $\mathrm{Mg}$ & $\%$ & 0.17 & 0.12 & 0.12 \\
\hline$S$ & $\%$ & 0.12 & 0.15 & 0.15 \\
\hline B & $\mathrm{mg} / \mathrm{kg}$ & 18.7 & 25.1 & 23.7 \\
\hline $\mathrm{Cd}$ & $\mathrm{mg} / \mathrm{kg}$ & 0.772 & 0.935 & 0.852 \\
\hline $\mathrm{Cr}$ & $\mathrm{mg} / \mathrm{kg}$ & 0.433 & 0.414 & 0.751 \\
\hline $\mathrm{Cu}$ & $\mathrm{mg} / \mathrm{kg}$ & 4.8 & 6.4 & 5.9 \\
\hline Mo & $\mathrm{mg} / \mathrm{kg}$ & $<0.11$ & $<0.12$ & 0.15 \\
\hline $\mathrm{Pb}$ & $\mathrm{mg} / \mathrm{kg}$ & 1.3 & 1.44 & 4.6 \\
\hline Dietary fiber & $\%$ & 8.58 & 9.31 & 8.62 \\
\hline Neutral detergent fiber & $\%$ & 15.8 & 19.8 & 17.8 \\
\hline Acid detergent fiber & $\%$ & 18.6 & 18.3 & 16.1 \\
\hline Sucrose & $\%$ & 45.7 & 51.8 & 50.1 \\
\hline Vitamin A & int. unit $/ \mathrm{kg}$ & $<1000$ & $<1000$ & $<1000$ \\
\hline Vitamin E & $\mathrm{mg} / \mathrm{kg}$ & 13.3 & 6.92 & 11 \\
\hline N-NO3 & $\mathrm{mg} / \mathrm{kg}$ & 128 & 236 & 299 \\
\hline
\end{tabular}

Table 4. Nutritional parameters and basic element contents of fresh carrot leaves.

\begin{tabular}{ccccc}
\hline Parameter & Unit & Untreated Control & $\mathbf{3 0 ~} \mathbf{g} / \mathbf{m}^{\mathbf{2}}$ & $\mathbf{5 0} \mathbf{g} / \mathbf{m}^{\mathbf{2}}$ \\
\hline Dry mass & $\%$ & 15.5 & 15.3 & 13.2 \\
\hline N-total & $\%$ & 3.32 & 4.3 & 4.24 \\
\hline N-NO3 & $\mathrm{mg} / \mathrm{kg}$ & 1170 & 1560 & 2340 \\
\hline
\end{tabular}

Previously, Ren et al. [21] and Waterford et al. [22] reported that EDN showed equal or even better nematicidal activity than methyl bromide in tests performed under in vitro conditions on Steinernema carpocapsae entomoparasitic nematodes used as insect biocontrol agents and thus readily available as a model organism. This comparison is of limited value because of different biology of Steinernema sp. when compared with root knot plant parasitic nematodes; however, until 2007, there was a complete lack of data validating the effects of EDN on Meloidogyne nematodes under field conditions. Chung et al. [29] were the first to demonstrate a high efficacy of EDN when applied to greenhouse plots infested with Meloidogyne spp. In their experiments, the application concentrations were equivalent to $2.5,5$, and $10 \mathrm{~g}$ of EDN $/ \mathrm{m}^{2}$, thus being substantially lower than the EDN application rate used in our study. These researchers claimed that even the lower EDN dose was sufficient for nematode control, the effect was slightly better than that obtained by methyl bromide. Concurrently, Rosskopf et al. [30] found high EDN efficacy against M. incognita, albeit under seminatural conditions only. They also observed that the numbers of beneficial nonpathogenic and nontarget free-living nematodes increased with the concentration of EDN tested, even if the increase was not statistically significant. Similar results were obtained by Mattner et al. [31], who tested EDN as a means of soil disinfestation in the nursery production of strawberries. In this case, EDN application to microplots reduced the num- 
bers of Tylenchus and Helicotylenchus spp. plant parasitic nematodes to levels equivalent to those achieved with methyl bromide, and the number of free-living nematodes increased with the application of EDN. The reasons for such an ambiguous effect are not, from the biological and toxicological perspective, quite clear. It can only be hypothesized that the predominant occurrence of plant parasitic nematodes in the rhizosphere of host plants can lead to a higher impact of EDN on this group of nematodes, whereas free living species can migrate from deeper soil horizons and replace the specimens previously eliminated by fumigation.

According to our findings, EDN represents a hopeful alternative to methyl bromide. The significant effect of the EDN treatment on nematode viability, its easy penetration into soil, decomposition into nontoxic products, and fertilizing effects [23,24] arising from the resulting decomposition products make the substance ideal for the regulation of $M$. hapla presence in soil. EDN is promising fumigant not only for its good efficacy but also because it was recently found that EDN does not accumulate in soil and is not likely to contaminate groundwater [26]. However, the acute toxicity of EDN does not allow untrained and unlicensed farmers to conduct field soil fumigations by themselves. These treatments must be performed by well-trained and experienced personnel equipped with the appropriate field machinery and protective equipment. Therefore, EDN application should be utilized as a preplant sanitation measure in plots with heavy M. hapla infestation. According to the authors' estimate, the economic feasibility of EDN treatment would be fair under conditions of the Czech Republic as it would be paid out even in the first year after treatment, and we can expect a longer effect of the EDN application. It is suggested that synthetic pesticide fumigations can be combined with biofumigation, e.g., [28], which can be applied in cases of lower M. hapla infestation. The application of appropriate biological agents for the replenishment of the soil microflora should be considered after EDN preplant application, as is common for soil fumigation with other fumigants, such as carbon disulfide, brommetan, dichloropropen or methyl bromide.

\section{Conclusions}

Results presented in this study shows strong effect of EDN treatment on viability of $M$. hapla nematode. Effective dose was $30 \mathrm{~g} / \mathrm{m}^{2}$, no phytotoxic effects were observed after EDN application. Some yield characteristics were positively influenced by EDN treatment as a result of additional nitrate supplied within EDN. According our result EDN is promising alternative of methyl bromide treatment against $M$. hapla nematode.

Author Contributions: Statistic analysis, writing, O.D.; samples evaluation, O.D., M.M.; conceptualization, M.Z., O.D.; EDN application, J.H.; supervision, manuscript review and editing, V.S. All authors have read and agreed to the published version of the manuscript.

Funding: This work was supported by the Technology Agency of the Czech Republic, Grant No. TH02030328 and Czech Ministry of Agriculture, Grant No. MZe-RO0418.

Institutional Review Board Statement: Not applicable.

Informed Consent Statement: Not applicable.

Data Availability Statement: Data are available on request.

Acknowledgments: The authors would like to express their thanks to Jiří Drbohlav, Jan Procházka, and Jana Wenzlová for technical assistance.

Conflicts of Interest: The authors declare no conflict of interest.

\section{References}

1. Abad, P.; Gouzy, J.; Aury, J.M.; Castagnone-Sereno, P.; Danchin, E.G.J.; Deleury, E.; Perfus-Barbeoch, L.; Anthouard, V.; Artiguenave, F.; Blok, V.C.; et al. Genome sequence of the metazoan plant-parasitic nematode Meloidogyne Incogn. Nat. Biotech. 2008, 26, 909-915. [CrossRef] [PubMed]

2. Sasser, J.N.; Freckman, D.W. A world perspective on nematology: The role of society. In Vistas on Nematology; Veech, J.A., Dickson, D.W., Eds.; Society of Nematologists: Hyattsville, MD, USA, 1987; pp. 7-14. 
3. Elling, A.A. Major emerging problems with minor Meloidogyne species. Phytopathology 2013, 103, 1092-1102. [CrossRef] [PubMed]

4. Douda, O.; Zouhar, M.; Mazáková, J.; Nováková, E.; Pavela, R. Using plant essences as alternative mean for northern root-knot nematode (Meloidogyne hapla) management. J. Pest Sci. 2010, 83, 217-221. [CrossRef]

5. Zouhar, M.; Rysanek, P.; Tesarova, B. Occurrence of the Root-Knot Nematode Meloidogyne hapla in the Czech Republic. Plant Dis. 2003, 87, 98. [CrossRef] [PubMed]

6. United Nations. Montreal protocol on substances that deplete the ozone layer. In United Nations Treaty Series; United Nations: New York, NY, USA, 1987; Volume 1522, p. 3.

7. Ducom, P. Methyl bromide alternatives. In Proceedings of the 9th International Conference on Controlled Atmosphere and Fumigation in Stored Product, Antalya, Turkey, 15-19 October 2012.

8. Zasada, I.A.; Halbrendt, J.M.; Kokalis-Burelle, N.; LaMondia, J.; McKenry, M.V.; Noling, J.W. Managing nematodes without methyl bromide. Ann. Rev. Phytopathol. 2010, 48, 311-328. [CrossRef] [PubMed]

9. Santos, B.M.; Gilreath, J.P.; Motis, T.N.; Noling, J.W.; Jones, J.P.; Norton, J.A. Comparing methyl bromide alternatives for soilborne disease, nematode and weed management in fresh market tomato. Crop Protect. 2006, 25, 690-695. [CrossRef]

10. Ozores-Hampton, M.; Castillo, G.; Navia, P. Efficacy of drip-injected nimitz (fluensulfone) to manage root-knot nematodes on tomato. In Tomato Institute Proceedings; University of Florida: Gainesville, FL, USA, 2016; pp. 10-12.

11. Grabau, Z.J.; Mauldin, M.D.; Habteweld, A.; Carter, E.T. Nematicide efficacy at managing Meloidogyne arenaria and non-target effects on free-living nematodes in peanut production. J. Nemat. 2020, 52, 10. [CrossRef] [PubMed]

12. Greco, N.; Aranda, J.L.; Saporiti, M.; Maccarini, C.; de Tommaso, N.; Myrta, A. Sustainability of European vegetable and strawberry production in relation to fumigation practices in the EU. Acta Hortic. 2020, 1270, 203-210. [CrossRef]

13. Fritsch, J.; Fargier-Puech, P.; Ramponi-Bur, C.; Du Fretay, G.; Fouillet, T.; Charles, P.; Descamps, S.; Myrta, A. French Experiences with Dimethyl Disulfide (DMDS) as a Nematicide in Vegetable Crops. Acta Hortic. 2014, 1044, 427-433. [CrossRef]

14. Curto, G.; Dongiovanni, C.; Sassanelli, N.; Santori, A.; Myrta, A. Efficacy of Dimethyl Disulfide (DMDS) in the Control of the Root-Knot Nematode Meloidogyne incognita and the Cyst Nematode Heterodera carotae on Carrot in Field Condition in Italy. Acta Hort. 2014, 1044, 405-410. [CrossRef]

15. Zouhar, M.; Douda, O.; Dlouhý, M.; Lišková, J.; Maňasová, M.; Stejskal, V. Using of hydrogen cyanide against Ditylenchus dipsaci nematode present on garlic. Plant Soil Environ. 2016, 62, 184-188. [CrossRef]

16. Stejskal, V.; Douda, O.; Zouhar, M.; Manasova, M.; Dlouhy, M.; Simbera, J.; Aulicky, R. Wood penetration ability of hydrogen cyanide and its efficacy for fumigation of Anoplophora glabripennis, Hylotrupes bajulus (Coleoptera) and Bursaphelenchus xylophilus (Nematoda). Int. Biodeterior. Biodegrad. 2014, 86, 189-195. [CrossRef]

17. Park, C.G.; Son, J.K.; Lee, B.H.; Cho, J.H.; Ren, Y. Comparison of ethanedinitrile (C2N2) and metam sodium for control of Bursaphelenchus xylophilus (Nematoda: Aphelenchidae) and Monochamus alternatus (Coleoptera: Cerambycidae) in naturally infested logs at low temperatures. J. Econom. Entomol. 2014, 107, 2055-2060. [CrossRef] [PubMed]

18. Lee, B.H.; Yang, J.O.; Beckett, S.; Ren, Y. Preliminary trials of the ethanedinitrile fumigation of logs for eradication of Bursaphelenchus xylophilus and its vector insect Monochamus alternatus. Pest Manag. Sci. 2017, 73, 1446-1452. [CrossRef] [PubMed]

19. Douda, O.; Stejskal, V.; Manasova, M.; Zouhar, M.; Hnatek, J. Inexpensive Screening Method to Validate the Efficacy of Ethanedinitrile Fumigant on the Forest Invasive Nematode Pest Bursaphelenchus xylophilus. Sustainability 2020, 12, 4765. [CrossRef]

20. Arbuzova, E.N.; Kulinich, O.A.; Chalkin, A.A.; Weis, V.; Magomedov, R.K.; Mordkovich, Y.B.; Kozyreva, N.I.; Ryss, A.Y. Efficacy of ethanedinitrile fumigant application against the pinewood nematode, Bursaphelenchus xylophilus (Nematoda: Aphelenchidae), in pine logs. Russ. J. Nematol. 2020, 28, 71-78.

21. Ren, Y.L.; Sarwar, M.; Wright, E.J. Development of cyanogen for soil fumigation. In Proceedings of the Annual International Research Conference on Methyl Bromide Alternatives and Emissions Reductions, Orlando, FL, USA, 6-8 November 2002 ; p. 4.

22. Waterford, C.J.; Ren, Y.L.; Mattner, S.; Sarwar, M. Ethanedinitrile (C 2 N 2)-a novel soil fumigant for insect, nematode, pathogen \& weed control. In Proceedings of the Annual International Research Confence on Methyl Bromide Alternatives and Emissions Reductions, Orlando, FL, USA, 31 October-3 November 2004; Volume 31, p. 5.

23. Stevens, M.; Freeman, J.H.; Boyd, S. Impact of ethanedinitrile applied by shank and hot gas for vegetable production. In Proceedings of the Annual International Research Conference on Methyl Bromide Alternatives and Emissions Reductions, San Diego, CA, USA, 13-15 November 2017; p. 3.

24. O'Brien, I.G.; Desmarchelier, F.J.M.; Yonglin, R. Cyanogen Fumigants and Methods of Fumigation Using Cyanogen. U.S. Patent No. 6,001,383, 14 December 1999.

25. Hall, M.; Adlam, A.; Matich, A.; Najar-Rodriguez, A.; Pal, P.; Brash, D. Quantification of hydrogen cyanide as a potential decomposition product of ethanedinitrile during pine log fumigation. N. Z. J. For. Sci. 2018, 48, 1-8. [CrossRef]

26. Zhou, W.; Zhang, Y.; Li, W.; Jia, H.; Huang, H.; Li, B. Adsorption isotherms, degradation kinetics, and leaching behaviors of cyanogen and hydrogen cyanide in eight texturally different agricultural soils from China. Ecotoxicol. Environ. Saf. 2019, 185, 109704. [CrossRef] [PubMed]

27. Stejskal, V.; Vendl, T.; Li, Z.; Aulicky, R. Minimal Thermal Requirements for Development and Activity of Stored Product and Food Industry Pests (Acari, Coleoptera, Lepidoptera, Psocoptera, Diptera and Blattodea): A Review. Insects 2019, 10, 149. [CrossRef] [PubMed]

28. Douda, O.; Zouhar, M.; Nováková, E.; Mazáková, J. Alternative methods of carrot (Daucus carota) protection against the northern root knot nematode (Meloidogyne hapla). Acta Agric. Scand. Sect. B Soil Plant Sci. 2012, 62, 91-93. 
29. Chung, B.J.; Kwon, O.Y.; Cho, C.S.; Kim, S.Y.; Myong, K.J.; Wan, H.; Lee, B.H.; Ryan, R. Efficacy of ethandinitrile to control root knot nematodes in yellow melon cultivation. In Proceedings of the Annual International Research Conference on Methyl Bromide Alternatives and Emissions Reductions, San Diego, CA, USA, 29 October-1 November 2007; p. 3.

30. Rosskopf, E.N.; Kokalis-Burelle, N.; Peterson, G.L.; Waterford, C. Preliminary investigation of ethanedinitrile for control of weeds and nematodes important to Florida production system. In Proceedings of the Annual International Research Conference on Methyl Bromide Alternatives and Emissions Reductions, San Diego, CA, USA, October 29-November 12007 ; p. 4.

31. Mattner, S.W.; Gounder, R.K.; Mann, R.C.; Porter, I.J.; Matthiessen, J.N.; Ren, Y.L.; Sarwar, M. Ethanedinitrile (C2N2)-a novel soil fumigant for strawberry production. In Proceedings of the V International Strawberry Symposium, Coolum, Australia, 5 September 2004; 197-204. 